\title{
Where food safety meets nutrition outcomes in livestock and fish value chains: a conceptual approach
}

Barbara Häsler ${ }^{1,2^{*}} \cdot$ Paula Dominguez-Salas ${ }^{2,3} \cdot$ Kimberly Fornace $^{2,4} \cdot$ Maria Garza ${ }^{2} \cdot$ Delia Grace $^{4}$ Jonathan Rushton ${ }^{1,2}$

${ }^{1}$ Leverhulme Centre for Integrative Research on Agriculture and Health, Royal Veterinary College, London, UK

${ }^{2}$ Royal Veterinary College, London, UK

${ }^{3}$ International Livestock Research Institute, Nairobi, Kenya

${ }^{4}$ London School of Hygiene and Tropical Medicine, London, UK

*Corresponding author details

Email: bhaesler@rvc.ac.uk

Tel $1+441707667037$

Tel $2+442079272518$

Fax +44 1707667051 
Integrated food safety and nutrition assessments

\section{Introduction}

Both nutrition and food safety researchers are increasingly concerned with providing safe and nutritious food to people in the face of rapid population growth, urbanisation, increasing food consumption and climate change (Lake et al. 2012), but working in disciplinary silos prevents effective collaboration with integrated data collection, analysis and interpretation. This results in incomplete evidence of the linkages between the fields, a failure to understand the integrated nature of the food systems-nutrition-health complex, lost opportunities and, in the worst case, policies that improve one aspect while impairing the other. Collaboration between food safety specialists (e.g. animal health or veterinary public health experts, or food technologists) and nutritionists is increasingly common, but often constrained due to limited understanding of disciplinary paradigms. This article seeks to assist those from the two communities collaborating on the integration of food safety and nutrition research in animal source foods (ASFs) by presenting a conceptual approach for the systematic integrated assessment of food safety and nutrition and discussing disciplinary approaches and their epistemological characteristics. Such work is timely, as the recently published Work Programme of the United Nations Decade of Action on Nutrition 20162025 highlights that "food safety needs to be integrated into the global food security and nutrition agenda to make significant progress in improving nutrition" (CFS OEWG-Nutrition 2017).

In many poor human population groups, the consumption of cheap energy-dense and nutrient-poor foods can cause a triple burden of malnutrition (Pinstrup-Andersen and Watson II 2011) with coexistence of calorie deficiency, micronutrient deficiency and over-nutrition within the same population, with negative health impacts (Agyei-Mensah and de-Graft Aikins 2010; Delisle et al. 2012; Hawkes and Ruel 2011; Vorster et al. 2011; Pingali 2015). These problems can be exacerbated by food-borne infectious diseases and chemical and physical hazards in food. Diarrhoeal diseases are one of the main causes of morbidity and mortality from infectious diseases (Murray et al. 2012) and the global burden of food-borne disease in 2010 was estimated at 33 million Disability Adjusted Life Years (Havelaar et al. 2015). The majority of the identified diarrhoeal disease burden is caused by zoonotic pathogens including salmonella, Escherichia coli, campylobacter, and helminths (Murray et al. 2012; WHO 2015). Non-typhoidal salmonellosis causes an estimated 94 million cases of gastroenteritis and 155,000 human deaths each year, and the majority ( $86 \%$ ) of these infections is thought to be food-borne (Majowicz et al. 2010). Apart from the debilitating consequences of people's food-borne illness, substantial economic costs also accrue due to the reaction of public and private institutions to disease. Public health and animal health services, industry bodies, farmers and consumer organisations aim to limit the losses by avoiding, containing, reducing, or removing 
Integrated food safety and nutrition assessments

hazards from food value chains, all of which require the use of scarce resources. Infection can contribute to under-nutrition by increasing the requirements for nutrients during an illness while also causing loss of appetite, reduced food intake, malabsorption and metabolic losses of nutrients (Gross et al. 2000). Fears of food-borne disease may discourage people from purchasing or consuming ASFs in both high (ILRI 2010) and low income settings (Cornelsen et al. 2016; Grace 2015). In countries where there are no substitution possibilities for the foods in question, consumers either put themselves at risk of food-borne disease when consuming the food due to the lack of alternatives, or they may increase the risk of malnutrition by excluding nutritious foods from their diets. For example in Egypt, a rise of human stunting was reported following the avian influenza outbreak in 2006 due to decreased poultry supply (and less dietary diversity) following mass culling of poultry to contain the outbreak (Kavle et al. 2015). Such dynamics can cause a vicious cycle of undernutrition and infection as malnourished individuals are increasingly susceptible to infections.

Although various studies highlight the potential trade-offs between food safety and nutrition outcomes, there is no conceptual guidance available that supports the concurrent assessment of nutrition and food safety in food systems. One study evaluated highly pathogenic avian influenza control measures in Indonesia considering the reduction of animal protein availability due to culling of poultry (lannotti et al. 2008). Another study examined the relationship between the microbial status of complementary foods and disease and nutritional status in children in Bangladesh (Islam et al. 2012). That study assessed the nutritional impacts of the food safety risk, finding contaminated foods were correlated with increased frequency of diarrhoea and malnutrition (as measured by anthropometry) in children. A joint Food Agriculture Organisation (FAO)-WHO meeting in 1995 evaluated the nutritional and disease effects of fermentation of milk and concluded fermentation could be an important method of increasing food safety (Motarjemi and Nout 1996). In this case, nutrition and disease outcomes were not opposing; fermentation was also found to be a method of increasing the nutritional value of food, primarily due to degradation of anti-nutritional factors. In contrast, an evaluation of the benefits and risks of seafood consumption in the United States considered both negative and positive impacts of contamination and nutrition on health (Committee on Nutrient Relationships in Seafood 2007). There the specific nutrient needs of vulnerable groups were compared to the potential negative consequences of exposure to seafood (potentially contaminated with heavy metals and residues) and intake recommendations were proposed taking into account the vulnerabilities of defined target groups (e.g. pregnant women, children $<12$ years of age, adolescent males). Likewise, impacts of specific food hazards on nutrition have been measured, such as the effect of exposure to aflatoxins on stunting. Aflatoxins are contaminants produced by fungi present in staple foods when conditions for growth are suitable (high moisture 
Integrated food safety and nutrition assessments

content and high temperature) due to improper management and climatic conditions (Villers 2014). In people, acute aflatoxin poisoning (aflatoxicosis) can cause acute hepatotoxic disease, whereas chronic subsymptomatic exposure is known to have nutritional and immunologic consequences (Grace et al. 2015; Smith et al. 2015; Williams et al. 2004). Any dose of aflatoxin can have carcinogenic effects (Williams et al. 2004). Studies in animals showed reduced protein and micronutrient absorption due to chronic exposure to aflatoxins (Zain 2011). Furthermore, Vitamin A deficiency was identified in chicken and camels fed with contaminated food while studies in humans have failed to show an association between Vitamin A and zinc deficiency and aflatoxin exposure (Gong et al. 2004). A longitudinal study conducted in West Africa in post weaning children over eight months of age showed an inverse correlation between the height for age score and exposure to aflatoxins; the difference in height gain between different groups of exposure was $1.7 \mathrm{~cm}$ (Gong et al. 2004). While these studies illustrate multiple links between food safety and nutrition outcomes, they remain isolated examples in a complex system and there is a dearth of scientific evidence on the systematic examination of these linkages.

We hypothesise that the interactions between food safety, nutrition and health outcomes are difficult to quantify in an integrated way due differing paradigms and methods used. To facilitate collaboration and communication between different food safety and nutrition communities and sectors we propose an approach to integrate six dimensions for the systematic simultaneous assessment of food safety and nutrition in livestock and fish value chains. In each step, key disciplinary paradigms and methodological characteristics that can cause pitfalls for integration are reviewed and explained. Then, recommendations for joint assessments are provided. This article is of relevance for both nutrition and food safety professionals to help them gain an understanding of approaches in the other discipline or sector and recognise opportunities for collaboration and the design or assessment of research or implementation projects.

\section{Overview of the linkages between food safety and nutrition in livestock and fish value chains}

The development of livestock and fish value chains, also commonly called ASF value chains, has been identified as a method to support the nutrition and livelihoods of rural and urban poor in developing countries (Dubé et al. 2012; Gelli et al. 2015; ILRI et al. 2011; Lee et al. 2012; World Bank 2007). Value chain approaches are increasingly utilised to characterise the dynamic and complex interactions and linkages within food production systems (Rich et al. 2011). Livestock and fish value chains include activities from production to consumption, involving natural resources and inputs (e.g. land, water, feed, veterinary drugs); primary production (e.g. livestock, fish); harvesting, 
Integrated food safety and nutrition assessments

processing and retailing (e.g. slaughter, food manufacturing) and finally the use of goods and services (e.g. ASF) by consumers. Apart from people, activities, and flows in the value chain, the value chain analysis also captures services and infrastructure (e.g. transport, financial services, veterinarians, government officials), legislation, standards, formal and informal rules, and socioeconomic factors and constraints. Different levels of value are realised when products or services change hands from suppliers to customers. These value chains have the potential to contribute to health and nutrition by increasing the availability and affordability of nutrient-rich ASF as well as improving nutrient content and decreasing foodborne disease risks (Gelli et al. 2015). Value chain approaches are increasingly promoted as a tool sensitive to nutritional concerns and to achieve nutritional goals (de Brauw et al. 2015). Moreover, they have been described as a suitable approach to inform food safety risk analysis in food systems (Kariuki et al. 2013; Taylor and Rushton 2011).

The key purpose of food systems is to produce safe and nutritious foods for the benefit of people; the ultimate outcomes being nutrition and health. Using the UNICEF framework of determinants of malnutrition, food safety can be conceptualised as a factor influencing both intake and disease, whereas food security influences intake (Fig. 1). Food safety refers to the conditions and processes that are applied to the food system to prevent foodborne illness and avoid severe health hazards. The food security concept was defined by the World Food Summit in 1996 as a situation that "exists when all people, at all times, have physical and economic access to sufficient, safe and nutritious food that meets their dietary needs and food preferences for an active and healthy life". This definition led to the establishment of the four pillars of food security, namely, availability, accessibility, utilisation and stability, facilitating their assessment. Food safety influences intake and disease in ASF value chains and ultimately nutrition and health in the following manner (see Fig. 2 and 3).

Impact on the availability of food, defined as "the availability of sufficient quantities of food of appropriate quality" (FAO 2006):

- Changes in the micro- or macro levels of nutrients from ASF along the value chain through manipulation, such as preservation (e.g. longer shelf life increases availability of ASF due to reduction in wastage), fortification (e.g. addition of micronutrients improves food composition), or adulteration (e.g. addition of water dilutes nutrients)

- Unhygienic practices in the value chain (e.g. contamination of ASF with foodborne pathogens or chemical contaminants or spoilage bacteria) can lead to ASF carrying health hazards and waste due to spoilage. Moreover, risk management measures implemented to 
Integrated food safety and nutrition assessments

manage food safety (e.g. recall of unsafe products) can lead to a decrease in the availability of ASF

Impact on the access to food, defined as "access by individuals to adequate resources (entitlements) for acquiring appropriate foods for a nutritious diet. Entitlements are defined as the set of all commodity bundles over which a person can establish command given the legal, political, economic and social arrangements of the community in which they live" (FAO 2006):

- Transformation of ASF, such as preservation (e.g. canning, pasteurisation) can lead to an increased value (reflected in a higher price) and therefore exclusion of poorer population groups from its consumption

- Avoidance of certain ASF when people fear the consequences for their own health of diseases potentially contracted from contaminated food products, or have ethical concerns related to the consumption of certain foods

- Employment in the ASF value chain generates income or gives people the possibility to acquire food more cheaply or as a form of payment

Impact on the utilisation of food, defined as "utilisation of food through adequate diet, clean water, sanitation and health care to reach a state of nutritional well-being where all physiological needs are met" (FAO 2006):

- Risk of infection with foodborne disease that impacts on the way nutrients are absorbed by the human body

- Inadequate preparation (e.g. overcooking of products) can lead to loss of nutrients

Impact on the stability of food, defined as "adequate food at all times [...] not risk losing access to food as a consequence of sudden shocks [...] or cyclical events [...]" (FAO 2006):

- Transformation of ASF, such as preservation (e.g. canning, pasteurisation) can lead to a longer shelf life and less vulnerability to seasonal fluctuations

- Foodborne pathogens can have cyclical (seasonal) patterns and therefore affect health and consequently nutrition at different magnitudes throughout the year.

These food safety related changes in the ASF value chains can either have a direct impact on nutrition (e.g. foodborne diarrhoea leading to malabsorption and weight loss, or adulteration reducing nutrient intake) or an indirect impact (e.g. wastage of food leading to a decrease in supply and thereby an increase in price, i.e. a reduction in access due to reduced affordability). Food security and nutrition assessments provide information on food availability, access, utilisation and stability as well as nutrient adequacy, the importance of a food product in peoples' diets and 
Integrated food safety and nutrition assessments

nutritional status. These assessment protocols have been developed within disciplinary paradigms of the nutrition community and differ from food safety assessment protocols developed by food safety experts. Consequently, quantitative information on the linkages described in Fig. 2 is largely lacking. To be able to address this knowledge and evidence gap, it is important to understand the tools, approaches and metrics used by the relevant disciplines and to discuss how these could be combined in joint research. In the next section, six relevant analytical dimensions are described to facilitate integration in research for food safety and nutrition.

\section{Analytical dimensions and their integration}

It is proposed to embed traditional risk analysis and nutrition assessment methods into a value chain analysis to improve understanding of the trade-offs between nutrition and food safety and to inform investment planning through the most promising interventions that promote nutrition and food safety simultaneously in ASF value chains (Fig. 2). With this information, policy makers can prioritise strategies depending on the risk preferences for affected stakeholders (e.g. farmers, retailers, consumers) and comparative advantages in implementing policies that reduce risks and promote benefits. Thereby, unintended consequences due to uni-disciplinary or uni-sectoral assessments can be avoided and resources be allocated efficiently.

The following analytical dimensions are described below: 1) identification of the system of interest; 2) value chain analysis; 3) food safety risk assessment; 4) nutrition assessment; 5) integrative analysis and assessment of risk management options; and 6) recommendations for decision-makers.

\subsection{Dimension 1: Identification of the system of interest}

For an integrated assessment of food safety and nutrition, it needs to be clear in what context it occurs and which components of the context it involves. The boundaries of the system determine what is included in the research. A deliberate focused drawing of boundaries, i.e. choosing which entities are inside the system and which are outside, is an essential first step in the analysis and should include consideration of geographical space, populations, time, biology, as well as the governance space.

The relevant ASF value chains and products of interest may be identified in several ways depending on the specific objectives of the assessment; potential criteria include the magnitude of production systems, specific nutritional deficiencies, foodborne pathogens, socio-economic characteristics, access to products, or health outcomes. When considering nutrition and health outcomes, the target populations are consumers of the ASFs; this may include people along the 
Integrated food safety and nutrition assessments

value chain as well as the general population. In nutrition studies, the primary focus commonly lies on specific population groups that are considered to be nutritionally vulnerable (Barrett 2010). Particularly children under five, pregnant and lactating women and/or elderly people are considered the most relevant groups to assess outcomes of nutrition studies and establish the nutrient needs of a population. Similarly, in a risk assessment for food safety, the target population may be a specific sub-population at highest risk for the hazard, such as pregnant women, immuno-deficient, allergic or nutritionally deficient people. Nonetheless, a general population approach is also possible. For example, studies directed at the general population can help to identify pockets of malnutrition (Chalimbaud et al. 2015) or to assess food safety risks to the general population. If data exist, a literature review can help to identify and prioritise vulnerable target populations by collating and assessing existing health and nutrition indicators. In the absence of such information, a general population focus may be deemed appropriate.

\subsection{Dimension 2: Value chain analysis}

Traditional value chain analysis includes four main components: a) mapping and characterising the people involved in the chain, b) assessing governance within the chain and the rules people use for making decisions, $c$ ) analysis of opportunities for upgrading within the chain, and d) the distribution of benefits and incomes among different value chain actors (Kaplinsky and Morris 2000). In addition to identifying geographical and temporal patterns, the people and businesses involved, and animal and product flows, quantities and prices, this analysis provides insight into the economic, social, cultural and regulatory factors and constraints that determine the dynamics of the chain (Taylor and Rushton 2011). This goes beyond the farm-to-fork approach ${ }^{1}$ traditionally used in food safety, which aims to ensure that food safety issues are addressed in a continuum that includes all stages of production in the food chain including primary production, harvesting, storage, processing, packaging, sales, and consumption. It commonly focuses on the technical aspects in the food chain. A value chain approach however, can be used to understand the motivations behind behaviours affecting the safety and the nutrient contents of the product, barriers to change (e.g. lack of market access, lack of knowledge, lack of inputs), as well as to identify groups that may be disproportionately bearing health risks or benefiting from the food product. According to Taylor and Rushton (2011), a value chain analysis provides a map of the organisation and flows of people, products, and processes; describes main points of production, spatial dimensions, infrastructure, markets and institutions involved; and summarises key statistics such as production, trade and consumption volumes, values, prices, and quantities. Moreover, the inclusion of information on

\footnotetext{
${ }^{1}$ Also known as "stable to table", "farm to table" or "boat to throat" (for aquatic animals)
} 
Integrated food safety and nutrition assessments

practices, rewards, cultural preferences, education and training of the people involved as well as the governance and equity of the chains allows identifying behavioural patterns that can impact on the food safety of ASF and nutrition risks in the value chain.

An example of this approach is work carried out to assess different ASF value chains in low and middle income areas of Nairobi, Kenya. There, the mapping of ruminant food systems following this approach allowed understanding of how the system functions, and identification of structural deficiencies and vulnerabilities, as well as opportunities for policy interventions thereby providing information for policy makers and institutions to discuss tailored improvement plans (Alarcon et al. 2017). A value chain framework was also applied to the broiler chicken meat system of Nairobi, producing key information about the system characteristics, governance and sanitary risks along the chain; this work formed the basis for a food safety assessment in the chain (Carron et al. 2015).

Food security and nutrition research has traditionally focused approaches and methods on the investigation of consumers, either at individual or household levels. Only in the past decade has a shift been observed to support and understand the coordination between different people in the value chain and how coordination and value addition affects nutrition (Hawkes and Ruel 2011). For example, to improve nutritional outcomes, this information can be used to upgrade specific food supply chains to increase the availability and access of nutritious and healthy food products. Additionally, value chain analysis can provide insight into what types of value can be added to increase consumer demand for nutritious foods and how nutritional improvements such as biofortification can affect consumer demand.

There is scope in value chains to promote the efficient production of nutrient-rich foods, nutrition-sensitive food processing, the reduction of food waste and increase in food safety simultaneously (McDermott et al. 2015) through an understanding of the economic, social, cultural and regulatory factors and barriers as well as opportunities to value addition in the chain. Without such an approach, there is a risk that sectoral policies may have negative consequences in other sectors. For example, the large scale culling of poultry to control avian influenza outbreaks in seven countries in Africa in $\mathbf{2 0 0 7}$ had severe impacts in terms of livelihoods and food security for many families (Sonaiya 2007). Similarly, enforcing regulations to limit the sale of food produced in unsafe environments may limit the availability of nutrient-rich food and discourage entry into the industry. Increasing food production without effective, feasible and accepted health regulations and support can increase the incidence of foodborne disease and the burden of non-communicable diseases (Webb and Block 2012) and/or trigger the emergence of risky consumption practices. For example, in the Democratic Republic of Congo and Tanzania, pigs heavily infected with the zoonotic Taenia 
Integrated food safety and nutrition assessments

solium parasite were excluded from formal markets with health regulation enforcement and consumed at home or sold on informal markets thereby putting people at risk of foodborne disease (Ngowi et al. 2004; Praet et al. 2010).

\subsection{Dimension 3: Food safety assessment in the value chain}

A traditional risk assessment as defined by the Codex Alimentarius Commission, a body jointly established by the WHO and FAO to harmonise food standards and codes of practice (WHO/FAO 2012), assesses the probability and consequences of introducing biological, chemical and physical hazards into food products. It can be adapted to be used in livestock and fish value chains as proposed previously (Taylor and Rushton 2011). For example, a value chain mapping including people and product profiling (involvement and interactions of people and products), geographical flows (routes of animals and products) and temporal mapping (seasonal fluctuations) provided the necessary data for a risk-based approach for targeted biological sampling for campylobacter in poultry value chains in Nairobi, Kenya (Carron et al. 2015).

The Codex Alimentarius Commission adopts a risk analysis approach to food safety, consisting of three stages: risk assessment, risk management and risk communication. The process of assessing risk is divided into four steps to determine the risks of a hazard to human health (WHO/FAO 2012):

1. Hazard identification: Identification of biological, chemical or physical agents present in a specific food or food type that can cause adverse health effects,

2. Hazard characterisation: Evaluation of the nature and severity of adverse health effects caused by these agents; this should include a dose-response assessment when appropriate,

3. Exposure assessment: Evaluation of the likely intake of the identified agents through food, and

4. Risk characterisation: Estimation of the probability of occurrence and the severity of potential adverse health effects in a population based on hazard identification and characterisation and the exposure assessment. These steps are applied throughout the food chain to determine the risks of a hazard to human health and capture the dynamics in the chain as suggested in Fig. 2 and Fig. 3.

Data for the risk assessment can be gathered from surveillance, survey and quality standard data, such as ISO-standards or Hazard Analysis and Critical Control Point (HACCP) data. Active and passive surveillance systems for a variety of foodborne and zoonotic pathogens are in place in both developed and developing countries (e.g. Racloz et al. 2012; Vrbova et al. 2010) and at times combined in international reporting platforms. Animal health surveillance is the systematic 
Integrated food safety and nutrition assessments

(continuous or repeated) measurement, collection, collation, analysis, interpretation, and timely dissemination of animal-health and welfare data from defined populations essential for describing health hazard occurrence and to contribute to the planning, implementation, and evaluation of riskmitigation actions (Hoinville et al. 2013). Such data are a useful source for food safety risk assessments and can be complemented by further data collection where there are data gaps. Nevertheless, in countries with limited resources, infrastructure and veterinary service capacity, many foodborne pathogens that do not cause clinical symptoms in animals and therefore productivity losses are not part of formal surveillance systems. In such cases, primary data need to be collected in the value chain.

The Codex Alimentarius Commission adopted the HACCP system to identify food hazards and measures for control (FAO 1997). This process is a legal requirement in many countries and is designed to assess and manage risks through the food chain, from production to consumption. Further guidelines have been developed to adapt it to small businesses and developing countries (FAO/WHO 2004). These methods evaluate the likelihood and impact of adverse events relating to specific food safety hazards in order to determine where to focus disease management strategies.

The Codex Alimentarius Commission also established principles and guidelines for nutritional risk analysis following the Codex Working Principles for Risk Analysis. This structured approach to assess public health and safety risks from food and food supplements provides a basis for food regulators and policy makers to establish risk management measures for characterised risks. Contrary to food safety hazards, nutritional risk analysis needs to take into account the probabilities of adverse health effects from both inadequate as well as excessive nutrient intake. This process identifies nutrient-related hazards present in specific foods that have the potential to cause adverse health effects if an inadequate or excessive amount is consumed and assesses the intake of these nutrients in a specific population and the probability and severity of resulting health problems (Richardson 2014). This method can be used to establish guidelines for minimum and maximum daily dietary intake. In addition, the Codex procedural manual advises risk-risk analysis to assess "risk associated with a significantly reduced or entirely avoided consumption of a nutritious, staple food in response to a dietary hazard such as a contaminant present in that food" (FAO/WHO 2013). Extending the use of the risk assessment framework to consider both food safety and nutrition can be used to provide a more balanced assessment of the health benefits and costs associated with a specific food product.

The desired outcome of the risk assessment is a measure of the probability of effects on human health attributable to a specific hazard, food, process, region, distribution pathway or some 
Integrated food safety and nutrition assessments

combination. Depending on the expertise of the team, limitations in theory or data obtainable, breadth of application, speed, transparency, the stage of the analysis, a desire for consistency of the approach and the responsiveness of risk characterisation measures to new evidence, risk assessment methods can range from qualitative through semi-quantitative to fully quantitative (FAO/WHO 2009). In any case, the risk assessment will require gathering data on the nature, frequency and severity of adverse effects detected at different levels of intake in different population groups as well as data on the frequency and quantity of intake of individual and defined population groups.

In resource scarce and/or informal settings, the latter being characterised by "non-linear, unregulated, heterogeneous and self-organising food value chains" (Grace et al. 2010), the integration of participatory methods (e.g. stakeholder analysis, outcome mapping, power mapping) and gender analysis in the risk assessment is recommended (Grace et al. 2010, 2008). The inclusion of participatory methodologies in risk assessments allow revealing unusual practices and insights, while gender analysis helps to assess incentive structures and capacities for risk management (Grace et al. 2008).

\subsection{Dimension 4: Nutrition assessment in livestock and fish value chains}

Table 1 summarises tools that can be used to assess nutrition and food security directly or indirectly. In nutrition, anthropometry and biomarker indicators are the most accurate measurement tools to assess nutrition outcomes, based on measurements of individual body dimensions and nutrient levels respectively. It is important to complement the anthropometric indices or blood or urine measurements with food security metrics and other information for a better understanding of the specific determinants of malnutrition and to design cost-effective interventions (Gerber and Torero 2013). Anthropometric and biomarker measurement are logistically burdensome and require experienced enumerators, and biomarkers are invasive and expensive. These indicators are the result of a number of factors, and other intermediate indicators may be more suited to assess the impact of value chain interventions.

Several data collection methods exist to assess individual dietary intake, such as keeping food records or diaries with portion size weight or estimation, conducting 24-hour recalls and food frequency questionnaire surveys. The information from these assessments can be used to calculate nutrient intakes directly or to create individual dietary diversity scores, which are a proxy of the micronutrient adequacy of the diet (Arimond et al. 2010; Ruel et al. 2010). Challenges related to data collection for individual dietary intake include respondent bias (over- or under reporting), recall bias, measurement error, and behaviour modification. 
Integrated food safety and nutrition assessments

To calculate nutrient intake directly, food composition tables are commonly used. These food composition tables are specific to countries, regions or populations consuming a similar diet, listing all common foods. However, despite the standardised process of developing food composition tables and analysing nutrient contents of food samples, there are high degrees of variation in nutrient composition due to variations in crop and animal production and processing and storage methods (Greenfield and Southgate 2003). For example, beef cattle fed on grass were found to have significantly higher levels of total omega-3 (n-3) and long chain $n-3$ fatty acids in their meat compared to grain-fed groups (Ponnampalam et al. 2006). Similarly, wild salmon showed a higher proportion of long chain n-3 fatty acids over the total lipid content in comparison to farmed salmon, which is attributed to the crustacean and marine fish diet (Henriques et al 2014). However, farmed salmon presented a higher absolute lipid content due to their diet, production system and physiology, which also included a higher absolute content of long chain n-3 fatty acids compared to wild species (Henriques et al. 2014). Post-production, processing methods (e.g. cooking, additives and storage practices) can cause substantial changes in the nutrient content of the final product; these changes in nutrient content can be measured using laboratory tests or be estimated from existing databases such as the USDA National Nutrient Database (USDA 2011). However, this level of detail is frequently not reflected in the usual dietary assessment as specific details can be difficult to obtain, both from the respondent and from the available food composition tables, leading to estimation errors. In addition, many countries do not have specific databases and some of their local food products do not exist in other databases (e.g. bush animals, specific breeds, specific types of meat or dairy products, etc.).

Food consumption scores that measure the number and frequency of specific foods consumed over a period of time ( 1 day to 7 days maximum), provide a measure of food security and access to these food products (FAO 2008). Food consumption scores can be calculated using the WFP methodology of scoring, which integrates food frequency data and nutritional importance of the food consumed (Wiesmann et al. 2009). Within this assessment, the individual food consumption score is compared with regional data in order to assess whether the diet is poor, borderline or adequate and likely to meet micronutrient needs.

In order to determine household food security, measurement tools like the FANTA Household Food Insecurity Access Scale (HFIAS), Coping Strategies Index, and Household Economy Approach are commonly used to measure food access (WFP 2009). The FANTA HFIAS survey measures uncertainty and anxiety over food access, perceptions of insufficient food quality and quantities and reported reductions of food intake and consequences of reduced intake (Coates et al. 
Integrated food safety and nutrition assessments

2007; IPC Global Partner 2008). The Coping Strategies Index measures coping strategies in response to decreased food security, such as dietary changes from preferred foods, reduction of meal numbers, methods of food acquisition, migration and rationing strategies (Maxwell and Caldwell 2008). The Household Economy Approach estimates food gaps by comparing resources, such as income and food sources, against food and essential need requirements (Save the Children UK 2000). This can include very detailed quantitative assessments (WFP 2009), simplified participatory assessments (WFP 2002) and rapid assessments based on interviews with key informants on how food access has changed in response to a crisis (SMART 2007). Months of adequate household food provisioning (MAHFP) can be used to determine food availability over the past 12 months (Bilinsky and Swindale 2010).

Other types of assessments employ participatory rural appraisal techniques; compiling community focus groups, interviewing key informants and conducting transect walks to determine the food security status of the community or target population (Beerlandt and Huysman 1999; ENCU/DPPA 2006; IFRC 2006; WHO 1995). Further, market analysis techniques that assess market structure, conduct and performance, have been applied to input and food markets as an early warning system for famines and food security crises by identifying potential factors limiting access to and availability of food (Kizito 2008).

Apart from the data collection methods described above to estimate the different indicators, other sources of (secondary) data can be used. For example, national statistics on the availability of food based on aggregated data can help to identify general trends such as food shortages, demand projections, and define objectives for agriculture production (Jones et al. 2013). Demographic and Health Surveys may include nutrition indicators and be used for long term monitoring of trends (e.g. UNICEF 2013) and the WHO's Nutrition Landscape Information System (NLiS) provides information on nutrition and development in the form of country profiles.

\subsection{Dimension 5: Integration of data and information and assessment of risk management}

\section{options}

The information from the risk assessment, the nutrition assessment and the value chain analysis allows us to identify points in the system where nutrients may be lost, how hazards enter the chain and where opportunities exist to increase the nutritional value, including food safety. By looking at the different dimensions described above, it is possible to recognise the interconnections between key components and to understand how they influence one another. It is at this stage where tradeoffs and/or co-benefits in terms of food safety and nutrition interventions and the direction of the 
Integrated food safety and nutrition assessments

effects becomes apparent. Moreover, it allows the identification of unintended consequences resulting from an action, e.g. a price increase related to improvement of food hygiene. Such information will help to describe the promising points of intervention that might lead to improved outcomes.

Ideally, unidirectional effects of interventions are identified that both improve or decrease food safety and nutrition and provide suitable entry points for effective risk management. For example, to reduce health and nutrition outcomes due to aflatoxins, an intervention strategy avoiding the build up of aflatoxin in grains (e.g. improved grain storage) would benefit human health and nutrition directly by reducing chronic and acute aflatoxicosis from the consumption of contaminated grains and derivatives in ASFs and indirectly through increased production and safety of ASFs because animals are not given contaminated feed. Similarly, dairy development projects have used value chain approaches to link smallholder dairy farmers and other value chain actors to increase the availability of dairy products for producers and consumers (Hawkes and Ruel 2011). These projects had the additional benefit of increasing incomes of producers, indirectly contributing to improved nutritional status within households and communities. They should be further investigated to account for the changes in foodborne disease risk due to increased exposure and changes in handling and storage practices. Generally, if nutrition and food safety goals appear to be conflicting, interventions can be designed to minimise negative consequences, such as through consumer education programmes.

An important aspect to consider when collating the different streams of information is the divergence in the analytical dimensions, as illustrated in Table 2. While food safety risk assessments are commonly concerned with the frequency of consumption and quantity consumed over a prolonged time period (e.g. average number of times a product is consumed per year), food security and nutrition assessments commonly focus on data collection over rather short time spans (e.g. 24 hour recall) and repeat data collection for longer term information is required. Another major difference is that food safety approaches tend to focus on one or a few commodities only, while food and nutrition assessments embrace the whole of the diet or focus on final outcomes (i.e. nutrition). Finally, food safety activities take a farm-to-fork approach, while nutrition research traditionally addresses the outcomes of value chain activities at the individual or household level. If these differing dimensions are to be bridged, it is important to identify data links and how these can be connected effectively.

Information from value chain analyses, such as the geographical patterns, nodes and animal and food product flows and quantities can be used to map the processes and identify critical control 
Integrated food safety and nutrition assessments

points. Additionally, data on the profitability of different activities within the value chain and the social, cultural and regulatory factors that influence decision-making can be used to identify incentives and disincentives for people in the value chain as a basis for the development of measures to improve food safety or increase nutritional content. The combined information allows designing intervention strategies that take into account the food system context and are potentially effective, feasible, holistic and acceptable. Once potential feasible interventions have been identified, the direct and indirect impacts such as changes in nutritional content and disease risks, or changes in consumer perceptions of acceptability, or changes in affordability through price or income changes, should be estimated.

The benefits of potential interventions include economic benefits, such as increased profits to value chain actors, and non-monetary benefits, such as the prevention of human morbidity and mortality or improved livelihoods. The costs of potential interventions include monetary costs of implementing the intervention and any associated health costs, such as a decrease in the nutritional content of the food or expected changes in consumption and demand. The costs and benefits of any potential intervention can be combined in cost-benefit or cost-effectiveness analysis, showing either the economic or health benefits of each dollar spent.

\subsection{Dimension 6: Recommendations for decision-makers}

To encourage uptake of the research results, information should be presented to policy makers in an integrated manner, showing all expected monetary and non-monetary costs and benefits of proposed interventions. The most frequently reported barriers to uptake of evidence by policy makers were described as "poor access to good quality relevant research, and lack of timely research output" (Oliver et al. 2014). There is an increasing body of evidence available about the effectiveness of knowledge synthesis and translation as well as evidence-based implementation (Grimshaw et al. 2012). An increasing number of guidelines exist about what to communicate, to whom, by whom and how (e.g. https://www.publicengagement.ac.uk/how/guides/engaging-policymakers). In any case, data used and any data gaps should be clearly communicated and sensitivity analysis conducted to test the robustness of any assumptions. To facilitate interpretation of results, the findings may be presented by component followed by recommendations based on the integrated findings.

\section{Discussion}

By explicitly addressing nutritional and foodborne disease outcomes in combination with value chain analysis, policies and interventions can be targeted to improve the overall health and well-being of 
Integrated food safety and nutrition assessments

people working in the chain and consumers. In this paper, we address the term "safe" commonly seen in food security definitions and translate the "One Health" concept into a practical approach that helps to bridge the gap between the Veterinary Public Health world, which is mainly concerned with food safety, animal health and productivity issues at a farm level, and the Nutritionist world, which is more focused on nutrition outcomes. Although the measurement of food and nutrition security often includes food safety from a conceptual point of view, the indicators for food safety are rarely included or considered, or only in a general, rather unspecific manner (Herforth et al. 2016).

The overview of the linkages between food safety and nutrition (Section 2) outlines the complex relationships that exist between food safety and nutrition. Multiple frameworks emerging in the food system, nutrition and health nexus describe similar complex and evolving relationships and the challenges and opportunities related to interdisciplinary working (Picchioni et al. 2017). With an increasing pressure on policymakers to generate co-benefits and efficiency (Picchioni et al. 2017), integrated studies are valuable to decision makers and should be an inherent part of any projects that look at leveraging agricultural value chains for nutrition. The integration of the analytical dimension described (in Section 3) should be done in cooperation between epidemiologists, veterinarians, medical doctors, economists, anthropologists, nutritionists, and social scientists in the spirit of interdisciplinarity benefiting from true closer cooperation across multiple sectors.

Although the conceptual approach presented here is designed to address many of the complex relationships between food safety and nutrition, it is not entirely comprehensive. The primary factor effecting food utilisation (i.e. "utilisation of food through adequate diet, clean water, sanitation and health care to reach a state of nutritional well-being where all physiological needs are met" (FAO 2006)) is individual health status. Illness and disease can lead to loss of appetite and poor absorption of the nutrients ingested. Child caring practices are another important component of food security for children as they are reliant on parents and other caretakers to provide safe and nutritious food.

As most of the steps require data collection, the whole approach may be costly and not always be feasible to undertake. Hence, it is advised to use secondary data where appropriate (e.g. national food surveys, existing value chain analysis) and focus data collection on the most relevant gaps identified. Participatory approaches are also useful in generating information rapidly and at low cost. Alternatively, it may be recommendable to target efforts at the most immediate needs, with additional analysis added over time to gain a more complete picture. 
Integrated food safety and nutrition assessments

Similar approaches, using a diverse set of metrics to represent economic and other criteria, have been used to evaluate environmental consequences of land use decisions (Bateman et al. 2013). Combining metrics from various disciplines allows decision makers to capture the full picture and evaluate which criteria are a priority, which in turn helps to take informed decisions on the best use of scarce resources. We anticipate that this article will contribute to the enhancement of the food safety aspect in nutrition research in livestock and fish value chains and to the promotion of an effective research and policy dialogue.

Acknowledgments This study was partly supported by the project "Rapid Integrated Assessment of Nutrition and Health Risks in Livestock and Fish Value Chains" funded by the Australian Centre for International Agricultural Research (ACIAR). It has been partly supported by the Consultative Group for International Agricultural Research (CGIAR) research program on Agriculture for Nutrition and Health. Barbara Häsler acknowledges support from the Leverhulme Centre for Integrative Research on Agriculture and Health (LCIRAH).

Conflict of Interest The authors declare that they have no conflict of interest. 
Integrated food safety and nutrition assessments

\section{References}

Agyei-Mensah, S., \& de-Graft Aikins, A. (2010). Epidemiological transition and the double burden of disease in Accra, Ghana. Journal of Urban Health : Bulletin of the New York Academy of Medicine, 87(5), 879-97.

Alarcon, P., Fèvre, E.M., Murungi, M.K., Muinde, P., Akoko, J., Dominguez-Salas, P., Kiambi, S., Ahmed, S., Häsler, B., \& Rushton, J. (2017). Mapping of beef, sheep and goat food systems in Nairobi - A framework for policy making and the identification of structural vulnerabilities and deficiencies, Agricultural Systems, 152, 1-17. doi:10.1016/j.agsy.2016.12.005

Arimond, M., Wiesmann, D., Becquey, E., Carriquiry, A., Daniels, M.C., Deitchler, M., Fanou-Fogny, N., Joseph, M.L., Kennedy, G., Martin-Prevel, Y., \& Torheim, L.E. (2010). Simple food group diversity indicators predict micronutrient adequacy of women's diets in 5 diverse, resourcepoor settings. Journal of Nutrition Supplement, 140, 2059S-69S.

Barrett, C.B. (2010). Measuring food insecurity. Science, 80-327, 825-828.

Bateman, I.J., Harwood, A.R., Mace, G.M., Watson, R.T., Abson, D.J., Andrews, B., Binner, A., Crowe, A., Day, B.H., et al. (2013). Bringing ecosystem services into use in the United Kingdom. Science, $341,6141,45-50$.

Beerlandt, H., \& Huysman, S. (1999). Manual for bottom-up-approach in Food Security interventions: analysis of target groups. International Fund for Agricultural Development, Rome, Italy.

Bilinsky, P., \& Swindale, A. (2010). Months of Adequate Household Food Provisioning (MAHFP) for Measurement of Household Food Access: Indicator Guide (v.4). Washington, D.C., USA: FHI 360/FANTA.

De Brauw, A., Gelli A., \& Summer, A. (2015). Identifying Opportunities for Nutrition-Sensitive ValueChain Interventions. IFPRI Research Brief 21.

Carron, M., Alarcon, P., Häsler, B., Fèvre, E.M., Karani, M., Muinde, P., Akoko, J., Onono, J., \& Rushton, J. (2015). Value chain mapping of broiler and indigenous chicken production systems in Nairobi as a first step to food safety and food security assessments. Proceedings of the 49th Kenya Veterinary Association Annual Scientific Conference, Busia, Kenya, 22-25 April, 2015.

CFS OEWG-Nutrition (2017). Work Programme of the UN Decade of Action on Nutrition [WWW Document]. URL http://www.fao.org/fileadmin/templates/cfs/Docs1617/OEWGNutrition/Meeting-

02/CFS_OEWG_Nutrition_2017_02_10_01_First_Draft_WP_Nutrtition_Decade.pdf (accessed 5.16.17).

Chalimbaud, J., Coates, J., \& Colaiezzi, B. (2015). Link NCA: A participatory and response oriented method for conducting a Nutritional Causal Analysis. Report for Action Contre La Faim. 
Integrated food safety and nutrition assessments

Coates, J., Swindale, A., \& Bilinsky, P. (2007). Household Food Insecurity Access Scale (HFIAS) for Measurement of Food Access: Indicator Guide. USAID, Washington DC, USA.

Committee on Nutrient Relationships in Seafood (2007). Seafood choices: balancing benefits and risks. Institute of Medicine of the National Academies, Washington DC, USA.

Cornelsen, L., Alarcon, P., Häsler, B., Amendah, D.D., Ferguson, E., Fevre, E.M., Grace, D., Dominguez-Salas, P., \& Rushton, J. (2016). Cross-sectional study of price and other drivers of demand for animal source foods in low-income urban areas of Nairobi, Kenya. BMC Nutrition, 2, 70. doi:10.1186/s40795-016-0109-z

Delisle, H., Ntandou-Bouzitou, G., Agueh, V., Sodjinou, R., \& Fayomi, B. (2012). Urbanisation, nutrition transition and cardiometabolic risk: the Benin study. British Journal of Nutrition, 107, 1534-1544.

Dubé, L., Pingali, P., \& Webb, P. (2012). Paths of convergence for agriculture, health, and wealth. Proceedings of the National Academy of Sciences of the United States of America, 109, 12294301.

ENCU/DPPA (2006). Guiding Principles for Rapid Nutrition Assessments. Emergency Nutrition Coordination Unit/ Disaster Prevention and Preparedness Agency, Addis Ababa, Ethiopia.

FAO (1997). Hazard Analysis and Critical Control Point (HACCP) System and Guidelines for its Application: Annex to CAC/RCP 1-1969, Rev. 3. Food and Agriculture Organization of the United Nations, Rome, Italy.

FAO (2006). Food security. Policy Brief, Issue 2. doi:10.1016/B978-0-12-375083-9.00127-6

FAO (2008). Methods to monitor the Human Right to adequate food. Volume II: An Overview of Approaches and Tools. Food and Agriculture Organization of the United Nations Rome, Italy.

FAO/WHO (2004). FAO/WHO guidance to governments on the application of HACCP in small and/or less-developed food businesses. FAO Food and Nutrition Paper 86, 1-84.

FAO/WHO (2009). Risk characterization of microbiological hazards in food: guidelines. Microbiological risk assessment series 17135.

FAO/WHO (2013). Codex Alimentarius Commission: Procedural Manual. Joint FAO/WHO Food Standards Programme. 21st Edition. World Health Organization and Food and Agriculture Organization of the United Nations, Rome, Italy.

Gelli, A., Hawkes, C., Donovan, J., Harris, J., Allen, S., Brauw, A. De, Henson, S., Johnson, N., Garret, J., \& Ryckembusch, D. (2015). Value Chains and Nutrition: A Framework to Support the Identification, Design, and Evaluation of Interventions. IFPRI Discussion Paper 01413

Gerber, N., \& Torero, M. (2013). Food and Nutrition Security Indicators: A Review. FOODSECURE working paper 05. 
Integrated food safety and nutrition assessments

Gong, Y., Hounsa, A., Egal, S., Turner, P.C., Sutcliffe, A.E., Hall, A.J., Cardwell, K., \& Wild, C.P. (2004). Postweaning exposure to aflatoxin results in impaired child growth: A longitudinal study in Benin, West Africa. Environmental Health Perspectives, 112, 1334-1338.

Grace, D. (2015). Food safety in low and middle income countries. International Journal of Environmental Research and Public Health, 12, 10490-10507.

Grace, D., Randolph, T., Olawoye, J., Dipelou, M., \& Kang'ethe, E. (2008). Participatory risk assessment: a new approach for safer food in vulnerable African communities. Development in Practice, 18, 611-618.

Grace, D., Makita, K., Ethe, E.K.K., \& Bonfoh, B. (2010). Safe food, fair food: Participatory risk analysis for improving the safety of informally produced and marketed food in sub Saharan Africa. Revue Africaine de Santé et de Productions Animales, 8 (S), 3-11.

Grace, D., Mahuku, G., Hoffmann, V., Atherstone, C. et al. (2015). International agricultural research to reduce food risks: case studies on aflatoxins. Food Security, 7(3), 569-582. doi:10.1007/s12571-015-0469-2

Greenfield, H., \& Southgate, D.A.T. (2003). Food composition data: production, management and use. Food and Agriculture Organization of the United Nations, Rome, Italy.

Grimshaw, J.M., Eccles, M.P., Lavis, J.N., Hill, S.J., \& Squires, J.E. (2012). Knowledge translation of research findings. Implementation Science, 7, 50.

Gross, R., Schoeneberger, H., Pfeifer, H., \& Preuss, H.A. (2000). The Four Dimensions of Food and Nutrition Security: Definitions and concepts. Food and Agriculture Organization of the United Nations, Rome, Italy.

Havelaar, A.H., Kirk, M.D., Torgerson, P.R., Gibb, H.J., Hald, T., Lake, R.J., Praet, N., Bellinger, D.C., de Silva, N.R., Gargouri, N., et al. (2015). World Health Organization Global Estimates and Regional Comparisons of the Burden of Foodborne Disease in 2010. PLOS Medicine, 12, 1-23. doi:10.1371/journal.pmed.1001923

Hawkes, C., \& Ruel, M.T. (2011). Value Chains for Nutrition. Proceedings of the IFPRI 2020 international conference "Leveraging Agriculture for Improving Nutrition and Health," February 10-12, 2011, New Delhi, India.

Henriques, J., Dick, J.R., Tocher, D.R., \& Bell, J.G. (2014). Nutritional quality of salmon products available from major retailers in the UK: content and composition of $n-3$ long-chain PUFA. British Journal of Nutrition, 112, 964-75.

Herforth, A., Nicolò, G.F., Veillerette, B., \& Dufour, C. (2016). Compendium of indicators for nutrition-sensitive agriculture. Food and Agriculture Organization of the United Nations, Rome, Italy. 
Integrated food safety and nutrition assessments

Hoinville, L.J., Alban, L., Drewe, J.A., Gibbens, J.C., Gustafson, L., Häsler, B., Saegerman, C., Salman, M., \& Stärk, K.D.C. (2013). Proposed terms and concepts for describing and evaluating animalhealth surveillance systems. Preventive Veterinary Medicine, 112(1-2), 1-12.

Iannotti, L., Barron, M., \& Roy, D. (2008). Animal Source Foods and Nutrition of Young Children: An Ex ante Analysis of Impact of HPAI on Nutrition in Indonesia, HPAI Research Brief. International Food Policy Research Institute, Washington DC, USA.

IFRC (2006). How to conduct a food security assessment: A step-by-step guide for National Societies in Africa. International Federation of Red Cross and Red Crescent Societies, Geneva, Switzerland.

ILRI (2010). Project Brief: Participatory Risk Assessment of pork in Ha Noi and Ha Tay, Vietnam. Improving the Competitiveness of Pig Producers in Vietnam Project Brief 3. Nairobi, Kenya: International Livestock Research Institute.

ILRI, CIAT, ICARDA, \& WorldFish (2011). More meat, milk and fish by and for the poor. CGIAR Research Program 3.7. Brochure. Nairobi, Kenya: International Livestock Research Institute.

Richardson, D.P. (2014). Nutritional risk analysis approaches for establishing maximum levels of vitamins and minerals in food (dietary) supplements. Report prepared for the International Alliance of Dietary/Food Supplement Associations.

IPC Global Partners (2008). Integrated Food Security Phase Classification Technical Manual. Version 1.1. Food and Agriculture Organization of the United Nations, Rome, Italy.

Islam, M., Ahmed, T., Faruque, A., Rahman, S., Das, S., Ahmed, D., Fattori, V., Clarke, R., Endtz, H., \& Cravioto, A. (2012). Microbiological quality of complementary foods and its association with diarrhoeal morbidity and nutritional status of Bangladeshi children. European Journal of Clinical Nutrition, 66, 1-5.

Jones, A.D., Ngure, F.M., Pelto, G., \& Young, S.L. (2013). What are we assessing when we measure food security? A compendium and review of current metrics. Advances in Nutrition: An International Review Journal, 4, 481-505.

Kaplinsky, R., \& Morris, M. (2000). A Handbook for value chain research. Prepared for IDRC. https://www.ids.ac.uk/ids/global/pdfs/VchNov01.pdf

Kariuki, S., Onsare, R., Mwituria, J., Ng'etich, R., Nafula, C., Karimi, K., Karimi, P., Njeruh, F., Irungu, P., \& Mitema, E. (2013). Improving food safety in meat value chains in Kenya. General interest paper: FAO/WHO project report. Food Protection Trends, 5, 172-179.

Kavle, J. A., El-Zanaty, F., Landry, M., \& Galloway, R. (2015). The rise in stunting in relation to avian influenza and food consumption patterns in Lower Egypt in comparison to Upper Egypt: results from 2005 and 2008 Demographic and Health Surveys. BMC Public Health, 15. 
Integrated food safety and nutrition assessments

doi:10.1186/s12889-015-1627-3.

Kizito, A. (2008). Structure-Conduct-Performance and Food Security. Famine Early Warning System NET Markets Guidance, No 2. United States Agency for International Development. Washington, USA.

Lake, I.R., Hooper, L., Abdelhamid, A., Bentham, G., Boxall, A.B., Draper, A., Fairweather-Tait, S., Hulme, M., Hunter, P.R., Nichols, G., \& Waldron, K.W. (2012). Climate change and food security: health impacts in developed countries. Environmental Health Perspectives, 120, 15201526.

Lee, J., Geref, G., \& Beauvais, J. (2012). Global value chains and agrifood standards : Challenges and possibilities for smallholders in developing countries. Proceedings of the National Academy of Sciences of the United States of America, 109, 12326-12331.

Majowicz, S.E., Musto, J., Scallan, E., Angulo, F.J., Kirk, M., O’Brien, S.J., Jones, T.F., Fazil, A., \& Hoekstra, R.M. (2010). The global burden of nontyphoidal Salmonella gastroenteritis. Clinical Infectious Diseases, 50, 882-9.

Maxwell, D.G., \& Caldwell, R. (2008). The Coping Strategies Index: Field Methods Manual. 2nd edition, Atlanta, GA, CARE, WFP, TANGO, Tufts University, USA.

McDermott, J., Johnson, N., Kadiyala, S., Kennedy, G., \& Wyatt, A.J. (2015). Agricultural research for nutrition outcomes - rethinking the agenda. Food Security, 7(3), 593-607.

Motarjemi, Y., \& Nout, M.J.R. (1996). Update: Food fermentation: a safety and nutritional assessment. Bulletin of the World Health Organization, 74, 553-559.

Murray, C.J.L., Vos, T., Lozano, R., Naghavi, M., Flaxman, A.D., Michaud, C., Ezzati, M., Shibuya, K., Salomon, J. A., Abdalla, S., et al. (2012). Disability-adjusted life years (DALYs) for 291 diseases and injuries in 21 regions, 1990-2010: a systematic analysis for the Global Burden of Disease Study 2010. Lancet, 380, 2197-223.

Ngowi, H.A., Kassuku, A.A., Maeda, G.E.M., Boa, M.E., \& Willingham, A.L. (2004). A slaughter slab survey for extra-intestinal porcine helminth infections in Northern Tanzania. Tropical Animal Health and Production, 36, 335-340.

Oliver, K., Innvar, S., Lorenc, T., Woodman, J., \& Thomas, J. (2014). A systematic review of barriers to and facilitators of the use of evidence by policymakers. BMC Health Services Research, 14, 2.

Picchioni, F., Aurino, E., Aleksandrowicz, L., Bruce, M. et al. (2017). Roads to interdisciplinarity working at the nexus among food systems, nutrition and health. Food Security, 9(1), 181-189. doi:10.1007/s12571-017-0658-2

Pingali, P. (2015). Agricultural policy and nutrition outcomes - getting beyond the preoccupation with staple grains. Food Security, 7(3), 583-591. 
Integrated food safety and nutrition assessments

Pinstrup-Andersen, P., \& Watson II, D.D. (2011). Food Policy for Developing Countries: The Role of Government in Global, National, and Local Food Systems. Cornell University Press, USA.

Ponnampalam, E.N., Mann, N.J., \& Sinclair, A.J. (2006). Effect of feeding systems on omega-3 fatty acids, conjugated linoleic acid and trans fatty acids in Australian beef cuts: potential impact on human health. Asia Pacific Journal of Clinical Nutrition, 15, 21-9.

Praet, N., Kanobana, K., Kabwe, C., Maketa, V., Lukanu, P., Polman, K., Matondo, P., Speybroeck, N., Dorny, P., \& Sumbu, J. (2010). Taenia solium cysticercosis in the Democratic Republic of Congo: How does pork trade affect the transmission of the parasite? PLOS Neglected Tropical Diseases, 4(9), e817. https://doi.org/10.1371/journal.pntd.0000817

Racloz, V., Ramsey, R., Tong, S., \& Hu, W. (2012). Surveillance of dengue fever virus: a review of epidemiological models and early warning systems. PLOS Neglected Tropical Diseases, 6, e1648. doi:10.1371/journal.pntd.0001648

Rich, K.M., Ross, R.B., Baker, A.D., \& Negassa, A., (2011). Quantifying value chain analysis in the context of livestock systems in developing countries. Food Policy, 36, 214-222.

Richardson D.P. (2014). Nutritional risk analysis approaches for establishing maximum levels of vitamins and minerals in food (dietary) supplements. Report prepared for the International Alliance of Dietary/Food Supplement Associations.

Ruel, M.T., Deitchler, M., \& Arimond, M. (2010). Developing simple measures of women's diet quality in developing countries : Overview. Journal of Nutrition Supplement, 140, 2048-2050.

Save the Children UK (2000). The Household Economy Approach: a resource manual for practitioners, Development Manual 6. Save the Children UK, United Kingdom.

SMART (2007). Standardized Monitoring and Assessment of Relief and Transitions [WWW Document]. URL http://www.smartindicators.org/

Smith, L.E., Prendergast, A.J., Turner, P.C., Mbuya, M.N.N., Mutasa, K., Kembo, G., \& Stoltzfus, R.J. (2015). The potential role of mycotoxins as a contributor to stunting in the SHINE trial. Clinical Infectious Diseases 2015; 61 (suppl_7), S733-S737. doi: 10.1093/cid/civ849

Sonaiya, E.B. (2007). Family poultry, food security and the impact of HPAI. World's Poultry Science Journal, 63.

Taylor, N., \& Rushton, J. (2011). A value chain approach to animal diseases risk management Technical foundations and practical framework for field application. Food and Agriculture Organization of the United Nations, Rome, Italy.

UNICEF (2013). Improving child nutrition. The achievable imperative for global progress. New York, USA. doi:978-92-806-4686-3

USDA Agricultural Research Service (2011). USDA National Nutrient Database for Standard 
Integrated food safety and nutrition assessments

Reference, Release 24. Nutrient Data Laboratory Home Page, http://www.ars.usda.gov/ba/bhnrc/nd

Vhurumuku, E. (2014). Food security indicators. Workshop on Integrating Nutrition and Food Security Programming for Emergency Response and Resilience Building. Nairobi, Kenya.

Villers, P. (2014). Aflatoxins and safe storage. Frontiers in Microbiology 2014, 5, 158.

Vorster, H.H., Kruger, A., \& Margetts, B.M. (2011). The nutrition transition in Africa: can it be steered in a more positive direction? Nutrients, 3, 4429-4441.

Vrbova, L., Stephen, C., Kasman, N., Boehnke, R., Doyle-Waters, M., Chablitt-Clark, A., Gibson, B., FitzGerald, M., \& Patrick, D.M. (2010). Systematic review of surveillance systems for emerging zoonoses. Transboundary Emerging Diseases, 57, 154-61.

Williams, J.H., Phillips, T.D., Jolly, P.E., Stiles, J.K., Jolly, C.M., \& Aggarwal, D. (2004). Human aflatoxicosis in developing countries: a review of toxicology, exposure, potential health consequences, and interventions. American Journal of Clinical Nutrition, 80(5), 1106-22.

Webb, P., \& Block, S. (2012). Support for agriculture during economic transformation: impacts on poverty and undernutrition. Proceedings of the National Academy of Sciences of the United States of America, 109, 12309-14.

WFP (2002). Food security analysis field kit. World Food Programme -Food Economy Group technical support unit, Sierra Leone.

WFP (2009). Emergency food security assessment handbook. Second Edition. World Food Programme, Rome, Italy.

WHO (1995). Field Guide on Rapid Nutritional Assessment in Emergencies. World Health Organization Regional Office for the Eastern Mediterranean, Alexandria, Egypt.

WHO (2015). WHO estimates of the global burden of foodborne diseases. Foodborne disease burden epidemiology reference group 2007-2015 268 p, World Health Organization. Geneva, Switzerland.

WHO/FAO (2012). Codex Alimentarius: International Food Standards [WWW Document]. URL http://www.codexalimentarius.org/

Wiesmann, D., Bassett, L., Benson, T., \& Hoddinott, J. (2009). Validation of the World Food Programme's Food Consumption Score and Alternative Indicators of Household Food Security. IFPRI Discussion Paper 00870, 1-105.

World Bank (2007). From Agriculture to Nutrition: Pathways, Synergies and Outcomes. Agriculture and Rural Development Department. The World Bank. Washington DC, USA.

Zain, M.E. (2011). Impact of mycotoxins on humans and animals. Journal of Saudi Chemical Society, $15,129-144$. 
Integrated food safety and nutrition assessments 
Integrated food safety and nutrition assessments

\section{FIGURE CAPTIONS}

Fig. 1 Overview of how food safety and food security link to the immediate causes of malnutrition

Fig. 2 Overview of the linkages between food safety and nutrition in livestock and fish value chains *Food-borne hazards can be microbiological, biochemical, or physical. Microbiological risks emerge, enter, and spread in value chains. ${ }^{* *}$ Disease control measures in animals (e.g. culling of infected animals) can reduce food safety risks, but also influence negatively the provision of animal source food. For reasons of clarity, these relationships are not illustrated in the figure

Fig. 3 Entry of food-borne hazards, influencing factors, and potential data sources to inform a risk assessment in animal source food value chains 
Table 1 Main characteristics, advantages and disadvantages of nutrition and food security measurement tools. Compiled based on Barrett (2010), Gerber and Torero (2013), Jones et al. (2013) and Vhurumuku (2014). HH = household.

\begin{tabular}{|c|c|c|c|c|c|}
\hline $\begin{array}{l}\text { Tool / metric / } \\
\text { indicator }\end{array}$ & Dimension & Definition - characteristics & Purpose & Advantages & Disadvantages \\
\hline Anthropometry & Nutrition & $\begin{array}{l}\text { Measurement of different body } \\
\text { dimensions to calculate several } \\
\text { indicators; weight for height, height } \\
\text { for age, weight for age, upper arm } \\
\text { circumference and body mass index } \\
\text { are the most commonly used. They } \\
\text { measure the degree of acute or } \\
\text { chronic malnutrition. There are } \\
\text { other less frequently used such as } \\
\text { head circumference or skinfolds. } \\
\text { Child growth indicators are } \\
\text { generally used by comparing to a } \\
\text { reference population }\end{array}$ & $\begin{array}{l}\text { Assess individual nutritional status } \\
\text { (growth) and determine prevalence } \\
\text { of malnutrition; identify groups at } \\
\text { risk; monitor nutrition changes; } \\
\text { evaluate nutrition impact of } \\
\text { interventions }\end{array}$ & $\begin{array}{l}\text { Gold standard to monitor growth; } \\
\text { accurate estimation of intra-HH } \\
\text { differences can help to understand } \\
\text { food allocation and utilisation; } \\
\text { suitable to assess nutritional impact } \\
\text { of interventions }\end{array}$ & $\begin{array}{l}\text { Does not provide information on } \\
\text { food intake (or underlying factors } \\
\text { thereof) and therefore needs to be } \\
\text { combined with other metrics; } \\
\text { laborious/time/resource intensive }\end{array}$ \\
\hline Biomarkers & Nutrition & $\begin{array}{l}\text { Biological samples from body fluids } \\
\text { such as blood plasma, urine, milk or } \\
\text { saliva that can provide information } \\
\text { on nutritional status with respect to } \\
\text { intake or metabolism of dietary } \\
\text { constituents. They can be the } \\
\text { dietary nutrients themselves or } \\
\text { end-products of the dietary } \\
\text { substances }\end{array}$ & $\begin{array}{l}\text { Assess individual response to } \\
\text { dietary intake; determine } \\
\text { prevalence of malnutrition; identify } \\
\text { groups at risk; monitor nutrition } \\
\text { changes; evaluate nutrition impact } \\
\text { of interventions }\end{array}$ & $\begin{array}{l}\text { Gold standard to asses } \\
\text { micronutrient status (specific tests); } \\
\text { support evidence-based clinical } \\
\text { guidance and effective health } \\
\text { interventions and policies }\end{array}$ & $\begin{array}{l}\text { Do not provide information on food } \\
\text { intake (or underlying factors } \\
\text { thereof) and therefore need to be } \\
\text { combined with other metrics; } \\
\text { laborious/time/resource intensive; } \\
\text { ethical concerns }\end{array}$ \\
\hline $\begin{array}{l}\text { Dietary intake } \\
\text { assessment }\end{array}$ & Nutrition & $\begin{array}{l}\text { Measurement of nutrient intake } \\
\text { through surveys, including } 24 \text { hour } \\
\text { records or recalls, with weighing or } \\
\text { estimation of portion sizes and use } \\
\text { of food composition tables to } \\
\text { calculate the nutrient content of } \\
\text { each food }\end{array}$ & $\begin{array}{l}\text { Assess individual nutrient intake; } \\
\text { identify adequacy of diet and } \\
\text { groups at risk; monitor nutrition } \\
\text { changes; evaluate nutrition impact } \\
\text { of interventions }\end{array}$ & $\begin{array}{l}\text { Measures quantity of food } \\
\text { consumed; can identify HH food } \\
\text { demand and intra-HH food } \\
\text { distribution if applied to different } \\
\text { HH members; determines changes } \\
\text { in consumption and dietary quality }\end{array}$ & $\begin{array}{l}\text { Laborious and resource intense, as } \\
\text { requires dietary intake data } \\
\text { collection as well as food } \\
\text { composition tables when they are } \\
\text { unavailable, and comparison with } \\
\text { reference groups. Prone to } \\
\text { respondent and recall bias, } \\
\text { measurement error, and behaviour } \\
\text { modification }\end{array}$ \\
\hline $\begin{array}{l}\text { Individual Dietary } \\
\text { Diversity Score } \\
\text { (IDDS): Women } \\
\text { Dietary Diversity }\end{array}$ & Nutrition & $\begin{array}{l}\text { Questionnaire based } 24 \text { hour recall } \\
\text { survey. Children are targeted from } \\
6 \text { to } 23 \text { months as well as women }\end{array}$ & $\begin{array}{l}\text { Assess the diversity of foods (but } \\
\text { not the amount) at the level of the } \\
\text { individual. Validated against } \\
\text { micronutrient (density) adequacy }\end{array}$ & $\begin{array}{l}\text { Proxy for diet adequacy for } \\
\text { micronutrients; less labour and } \\
\text { resource intense than } \\
\text { measurement of dietary intake }\end{array}$ & $\begin{array}{l}\text { No information about quantity } \\
\text { consumed or frequency of } \\
\text { consumption of food groups }\end{array}$ \\
\hline
\end{tabular}




\begin{tabular}{|c|c|c|c|c|c|}
\hline $\begin{array}{l}\text { Score (WDDS), Child } \\
\text { Minimum Dietary } \\
\text { Diversity }\end{array}$ & & & $\begin{array}{l}\text { for micronutrients it provides an } \\
\text { indirect measure of micronutrient } \\
\text { adequacy of the diet }\end{array}$ & & \\
\hline $\begin{array}{l}\text { Household Dietary } \\
\text { Diversity Score } \\
\text { (HDDS) }\end{array}$ & $\begin{array}{l}\text { Food } \\
\text { security }\end{array}$ & $\begin{array}{l}\text { Questionnaire based } 24 \text { hour recall; } \\
\text { unit of investigation is the HH. It is } \\
\text { validated against HH calorie } \\
\text { acquisition and provides an } \\
\text { estimate of food security. It also } \\
\text { gives information about the variety } \\
\text { of diets that according to several } \\
\text { studies is associated with improved } \\
\text { health outcomes }\end{array}$ & $\begin{array}{l}\text { Assess the dietary diversity of the } \\
\mathrm{HH} \text {. Validated against } \mathrm{HH} \text { calorie } \\
\text { acquisition it provides a measure of } \\
\text { food security }\end{array}$ & $\begin{array}{l}\text { Proxy for HH food access / energy } \\
\text { availability; less labour and } \\
\text { resource intense than } \\
\text { measurement of dietary intake; } \\
\text { provides information on diversity of } \\
\text { different food groups and data can } \\
\text { be disaggregated by sex of HH } \\
\text { head, strata and other areas of } \\
\text { interest; suitable for monitoring of } \\
\text { changes due to interventions (e.g. } \\
\text { impact on HH's dietary habits) }\end{array}$ & $\begin{array}{l}\text { No information about quantity, } \\
\text { frequency of consumption of food } \\
\text { groups nor a weight on these } \\
\text { according to the nutritional value; } \\
\text { non-context-specific - it is advisable } \\
\text { to adapt indicators to context- } \\
\text { specific data for food groups and } \\
\text { weighting; measurement challenges }\end{array}$ \\
\hline $\begin{array}{l}\text { Food Consumption } \\
\text { Score (FCS) }\end{array}$ & $\begin{array}{l}\text { Food } \\
\text { security }\end{array}$ & $\begin{array}{l}\text { Questionnaire based survey. The } \\
\text { FCS is an indirect indicator based on } \\
\text { consumption frequency } \\
\text { information that uses weighted } \\
\text { categories to measure food } \\
\text { security/insecurity }\end{array}$ & $\begin{array}{l}\text { Assess dietary diversity of the } \mathrm{HH} \text { as } \\
\text { a measure of food security }\end{array}$ & $\begin{array}{l}\text { Frequency of consumption and } \\
\text { diversity of diet allows determining } \\
\text { risk of micronutrient deficiencies } \\
\text { and of severe food access issues; } \\
\text { minimal data collection and } \\
\text { information is straightforward to } \\
\text { collect; straightforward calculation } \\
\text { of the indicator; positive association } \\
\text { with nutrient quality of diets and } \\
\text { child anthropometry }\end{array}$ & $\begin{array}{l}\text { No information about seasonal } \\
\text { changes and intra- HH food } \\
\text { distribution; does not capture } \\
\text { changes in food consumption; } \\
\text { depends on determination of cut- } \\
\text { offs that may over or } \\
\text { underestimate food security; non- } \\
\text { context-specific - it is advisable to } \\
\text { adapt indicators to context-specific } \\
\text { data for food groups and weighting; } \\
\text { measurement challenges }\end{array}$ \\
\hline
\end{tabular}




\begin{tabular}{|c|c|c|c|c|c|}
\hline $\begin{array}{l}\text { Coping Strategies } \\
\text { Index (CSI/rCSI) }\end{array}$ & $\begin{array}{l}\text { Food } \\
\text { security }\end{array}$ & $\begin{array}{l}\text { Participatory adaptation-based } \\
\text { measure that uses participatory } \\
\text { rural assessment to capture } \\
\text { quantity and quality of food } \\
\text { consumed }\end{array}$ & $\begin{array}{l}\text { Assess consumption behaviours as } \\
\text { a monitoring tool to inform } \\
\text { development programmes and } \\
\text { guide aid targeting }\end{array}$ & $\begin{array}{l}\text { A reduced version that limits the } \\
\text { strategies to } 5 \text { is reported to lose } \\
\text { the context value, but being useful } \\
\text { to compare food security status } \\
\text { across context }\end{array}$ & On its own, it is not very meaningful \\
\hline $\begin{array}{l}\text { Household } \\
\text { Economy Approach } \\
\text { (HEA) }\end{array}$ & $\begin{array}{l}\text { Food } \\
\text { security }\end{array}$ & $\begin{array}{l}\text { An analytical framework used in } \\
\text { poverty and vulnerability } \\
\text { assessments that uses participatory } \\
\text { rural assessment methods }\end{array}$ & $\begin{array}{l}\text { Assess consumption behaviours and } \\
\text { livelihood information }\end{array}$ & $\begin{array}{l}\text { Context specific; provides in-depth } \\
\text { understanding of the nature of food } \\
\text { security; can predict the effect of } \\
\text { potential hazards on livelihood and } \\
\text { food security (vulnerability) }\end{array}$ & $\begin{array}{l}\text { It is not designed to produce a } \\
\text { quantifiable output }\end{array}$ \\
\hline $\begin{array}{l}\text { Household Food } \\
\text { Insecurity and } \\
\text { Access Scale } \\
\text { (HFIAS) }\end{array}$ & $\begin{array}{l}\text { Food } \\
\text { security }\end{array}$ & $\begin{array}{l}\text { Experience-based indicator that is } \\
\text { used to assess and monitor } \\
\text { prevalence of } \mathrm{HH} \text { food insecurity }\end{array}$ & $\begin{array}{l}\text { Assess consumption behaviours, } \\
\text { sufficiency and psychological } \\
\text { factors. It provides a simple tool for } \\
\text { targeting, monitoring, and } \\
\text { evaluation }\end{array}$ & $\begin{array}{l}\text { Positive association with } \mathrm{HH} \\
\text { socioeconomic indicators, dietary } \\
\text { diversity, lower risk of } \\
\text { undernutrition }\end{array}$ & $\begin{array}{l}\text { Insufficient quality (includes variety } \\
\text { and preferences of the type of } \\
\text { food) }\end{array}$ \\
\hline $\begin{array}{l}\text { Household Hunger } \\
\text { Scale (HHS) }\end{array}$ & $\begin{array}{l}\text { Food } \\
\text { security }\end{array}$ & $\begin{array}{l}\text { Experience-based indicator to } \\
\text { assess and monitor prevalence of } \\
\text { hunger }\end{array}$ & $\begin{array}{l}\text { Assess consumption behaviours and } \\
\text { extreme insufficiency }\end{array}$ & $\begin{array}{l}\text { Captures more severe behaviours; } \\
\text { simple to use }\end{array}$ & $\begin{array}{l}\text { Reduced metric that lacks wider } \\
\text { dimensions of food security, such as } \\
\text { quality }\end{array}$ \\
\hline $\begin{array}{l}\text { Household } \\
\text { Consumption and } \\
\text { Expenditure } \\
\text { Surveys }\end{array}$ & $\begin{array}{l}\text { Food } \\
\text { security }\end{array}$ & $\begin{array}{l}\text { Poverty measure that uses } \\
\text { consumer price indices and } \mathrm{HH} \\
\text { socio-economic status }\end{array}$ & Assess food acquisition & $\begin{array}{l}\text { Properly collected data allow for } \\
\text { population-level estimate of diet } \\
\text { quality; less costly and time } \\
\text { consuming than other methods }\end{array}$ & $\begin{array}{l}\text { Assumes that food acquisition } \\
\text { equals food consumption; food } \\
\text { expenditure data only capture } \\
\text { monetary value of food; does not } \\
\text { account for individual consumption, } \\
\text { food wasted or food consumed that } \\
\text { does not need to be paid for }\end{array}$ \\
\hline
\end{tabular}

Table 2 Comparison of key characteristics in food safety and nutrition research

\begin{tabular}{|l|l|l|}
\hline & Food safety research & Nutrition research \\
\hline Unit of analysis & $\begin{array}{l}\text { Food chain; often following products from farm to fork/stable to } \\
\text { table/boat to throat }\end{array}$ & Human populations; individual level \\
\hline Purpose & $\begin{array}{l}\text { Assess risk of foodborne hazards, identify points of intervention to } \\
\text { improve food safety }\end{array}$ & $\begin{array}{l}\text { Assess the nutritional status of an individual or a population, which is the } \\
\text { result of many inter-related factors, including dietary intake, physical } \\
\text { activity and disease }\end{array}$ \\
\hline Data collection & $\begin{array}{l}\text { Primary (including biological sample collection and laboratory } \\
\text { testing) and secondary data collection at multiple levels including } \\
\text { hazards (e.g. review of biological characteristics), animals (e.g. }\end{array}$ & $\begin{array}{l}\text { Direct data collection at individual individuals (often those nutritionally } \\
\text { pore vulnerable, e.g. children and women). Indirect data related to } \\
\text { potential consumption (i.e. food security) can be informative (at }\end{array}$ \\
\hline
\end{tabular}




\begin{tabular}{|c|c|c|}
\hline & $\begin{array}{l}\text { prevalence, incidence, outbreak data), food and the food chain } \\
\text { (e.g. contamination levels of equipment, facilities, products etc. } \\
\text { and risk mitigation measures in place) as well as consumers (e.g. } \\
\text { dietary consumption data; consumer food storage and handling } \\
\text { practices; public health measures like incidence, prevalence, } \\
\text { outbreaks, disability adjusted life years; capacity and } \\
\text { implementation of risk mitigation measures) }\end{array}$ & household level, at village level, at country level) \\
\hline $\begin{array}{l}\text { Methods and } \\
\text { measures }\end{array}$ & $\begin{array}{l}\text { Literature reviews and analyses of primary and secondary data } \\
\text { listed above in a qualitative or quantitative way to estimate } \\
\text { the probability of the intake of an identified and characterised } \\
\text { undesired hazard and the size of the consequences following } \\
\text { intake in a given population. A hazard can be biological, } \\
\text { chemical or physical. For the quantitative analyses, } \\
\text { probabilistic modelling is often used }\end{array}$ & $\begin{array}{l}\text { ABCD methods of nutritional assessment: } \\
\text { - Anthropometric measurements (of body composition), } \\
\text { - Biochemical measurements in people (i.e. nutrient levels, } \\
\text { generally in blood or urine), } \\
\text { - Clinical assessment (specific symptoms, pathognomonic of } \\
\text { nutrient deficiencies) } \\
\text { - Dietary assessment (e.g. recall, weighed records, etc.) }\end{array}$ \\
\hline $\begin{array}{l}\text { Data collection } \\
\text { mechanisms }\end{array}$ & $\begin{array}{l}\text { Regular through food chain and public health surveillance or } \\
\text { sporadic through targeted surveys }\end{array}$ & $\begin{array}{l}\text { Regular through surveillance and monitoring systems or sporadic through } \\
\text { targeted surveys }\end{array}$ \\
\hline
\end{tabular}

